Volume 10 Number 4, October-December 2016: pp. 605-820. Copyright (c) 2015-2016 FIAT JUSTISIA. Faculty of Law, Lampung University, Bandarlampung, Lampung, Indonesia. ISSN: $1978-5186$ | e-ISSN: 2477-6238.

Open Access: http://jurnal.fh.unila.ac.id/index.php/fiat

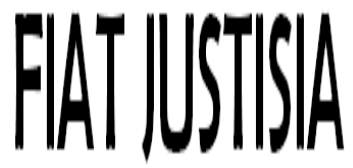

Fiat Justisia is licensed under a Creative Commons Attribution 4.0 International License, which permits unrestricted use, distribution, and reproduction in any medium, provided the original work is properly cited.

\title{
HUKUM, MORAL, DAN KEKUASAAN DALAM TELAAH (Hukum adalah Alat Teknis Sosial)
}

\author{
Legal, Moral, and Authority in the Study \\ (Law is A Tool of Social Engineering)
}

\section{Fithriatus Shalihah}

Oksep Adhayanto

Fakultas Hukum Universitas Islam Riau

Email: fithriatus@law.uir.ac.id

\begin{abstract}
The negative impact of the use of law as a means of changing society in authoritarian countries is seen already clear when in authority a regime that was decades on authority in Indonesia. The regime overcome all the forces that exist in society and the bureaucracy is crucial. Political parties in that era were not independent. The decisions in the field of legislation more influenced by the government's political vision. Here, the law has been used as synonymous with power, so that can not be distinguished more clearly, where the law where power, where "rechtsstaat" and where "machtstaat", where state laws and which countries tyranny legitimized by law. The law should be given charges philosophical truth values are deduced from the principles of the law by the authorities, in fact the loaded power itself that must be regarded as truth. Manipulation of the truth that's going on here is misdirection logic through language games that the law is the same as the laws in the flow of positivism.
\end{abstract}

Keywords: Legal, Moral and Authority

\begin{abstract}
Abstrak
Dampak negatif penggunaan hukum sebagai sarana perubahan masyarakat dalam negara otoriter terlihat sudah secara terang benderang ketika berkuasanya sebuah rezim yang puluhan tahun berkuasa di Indonesia. Rezim tersebut mengatasi semua kekuatan yang ada dalam masyarakat dan birokrasinya sangat menentukan. Partai-partai politik pada era itu tidak
\end{abstract}


mandiri. Keputusan-keputusan di bidang legislasi lebih banyak diwarnai oleh visi politik pemerintah. Disini hukum telah dijadikan identik dengan kekuasaan, sehingga tidak dapat dibedakan lagi secara tegas, mana hukum mana kekuasaan, mana rechtsstaat dan mana machtstaat, mana negara hukum dan mana negara tirani yang dilegitimasi secara hukum. Hukum yang seharusnya diberi muatan-muatan nilai-nilai kebenaran filosofis yang dideduksi dari asas-asas hukum oleh kekuasaan, pada kenyataanya diberi muatan kekuasaan itu sendiri yang harus dipandang sebagai kebenaran. Manipulasi kebenaran yang terjadi disini berakar penyesatan logika melalui permainan bahasa (language of the game) bahwa hukum itu sama dengan undang-undang dalam aliran positivisme.

\section{Kata Kunci: Hukum, Moral, dan Kekuasaan}

\section{A. Pendahuluan}

Perkenankan, dalam refleksi berpikir pada tulisan ini penulis memulai dengan sebuah kalimat Indonesia dalam carut marut. Dilatar belakangi dengan berbagai-bagai persoalan penegakan hukum di negeri ini yang semakin memprihatinkan. Hukum di suatu negara bertujuan untuk memberikan ketertiban dan keamanan bagi masyarakat. Ketertiban tersebut akan terjaga apabila masyarakat menaati hukum yang ada. Menurut Van Apeldorn, hukum tidak cukup diartikan sebagai aturan yang mengikat warganya saja, melainkan harus memiliki aspek keadilan dan asas lain yang berguna melindungi warganya dengan adil, dan menjamin kepastian hukum bagi setiap warga negara, tanpa kecuali. Agar terwujudnya kepastian hukum bagi setiap warga negara, penting bagi seluruh masyarakat untuk mematuhi hukum/perundang-undangan yang berlaku. Dan hal ini juga berlaku bagi aparat penegak hukum dalam menjalankan tugas dan fungsinya. Setidaknya dalam pengamatan penulis, dalam kajian keilmuan, ada dua kubu yang sedang berseteru dan bertarung dalam pentas hukum nasional sebagai akibat dari adanya perbedaan pandangan tentang ontologi hukum berikut metode penemuan dan pengkajian terhadap hukum.

Kubu yang pertama bisa disebut sebagai kubu normatif (positivis) yang menyatakan bahwa ilmu hukum merupakan suatu disiplin yang sui generis, yakni ilmu jenis sendiri dengan karakternya yang khas yang bersifat normatif. ${ }^{1}$ Sebagai konsekwensi logis dari karakternya yang khas normatif maka penelitian sosial tentang hukum atau sosiolegal research dianggap sebagai bukan penelitian hukum. $^{2}$ Sedangkan kubu yang kedua

${ }^{1}$ Hadjon, Philipus M. dan Djatmiati, Tatiek Sri. (2005). Argumentasi Hukum. Yogyakarta: Gajahmada University Press, p. 1.

${ }^{2}$ Marzuki, Peter Mahmud. (2005). Penelitian Hukum. Jakarta: Prenada Media, p. 87-91. 
berpandangan bahwa ilmu hukum merupkan disiplin ilmu yang bersifat interdisipliner, sehingga hukum tidak akan dipahami dengan baik tanpa melibatkan kajian-kajian ilmu-ilmu yang lain terhadap hukum. ${ }^{3}$

Kubu yang penulis sebut pertama bisa dikatakan sebagai pendukung aliran pemikiran doktrinal yang mengkonsepkan hukum sebagai sesuatu yang berlandaskan pada logika normatif. Sebaliknya kubu yang kedua bisa dikatakan sebagai kubu penganut aliran pemikiran non doktrinal yang mengkonsepkan bahwa logika hukum yang berlandaskan pada nomos (realitas sosial).

Trubek berpendapat, dan kemudian lebih dipertegas oleh pendapat Satcipto rahardjo, yang mengemukakan bahwa dunia hukum yang semula bersifat esoterik yang mengklaim sebagai suatu wilayah yang otonom, tidak dapat dipertahankan lebih lama lagi, disebabkan adanya dua faktor, yaitu: ${ }^{4}$

1. Ketidakmampuan sistem hukum yang ada untuk dijadikan suatu sarana pengaturan masyarakat Indonesia masa kini. Hal ini dikarenakan adanya proses transformasi politik, dengan akibat hukum kehilangan cengkramannya di tengah masyarakat.

2. Adanya suatu keinginan terhadap pembentukan Indonesia baru dengan sarana hukum yang lebih akomodatif serta responsif terhadap kebutuhan hukum masyarakat.

Kecenderungan pemerintah yang memerintah dengan kekuasaan demi menegakkan kewibawaan terlihat semenjak awal (orde lama) sampai orde baru, dengan masa pemerintahan Presiden Soeharto yang mencapai 32 tahun. Setelah waktu yang lama tersebut kemudian orang mulai terhenyak dan sadar untuk memperjuangkan hukum menjadi panglima yang harus membawa perubahan pada bangsa. Mengedepankan hukum yang mampu pula bekerja dengan efektif di tengah-tengah masyarakat. Sekitar tahun 1998 kemudian dimulai orde dengan suatu orde yang baru, dinamakan orde reformasi, yang kemudian ingin mengedepankan moral terhadap hukum dengan didasarkan adanya keinginan untuk melaksanakan hukum, dan mengembalikan kewibawaan hukum.

\section{B. Pembahasan}

1. Hukum, Moral dan Kekuasaan dalam Telaah Law is a Tool of Social Engineering

Sampailah Indonesia saat ini pada sebuah orde yang penulis gamang menyebutnya sebagai orde apa. Sebutlah masih kelanjutan orde reformasi

\footnotetext{
${ }^{3}$ Rahardjo, Satjipto. (1986). Ilmu Hukum. Bandung: Alumni, p. 5.

4 Ali, Achmad. Menguak Tabir Hukum (Suatu kajian Filosofis Dan Sosiologis): dalam Tulisan Hukum Sebagai Kenyataan dalam Masyarakat. Jakarta: PT. Toko Gunung Agung Tbk., p. 53-54.
} 
dengan segala tujuannya dalam penegakan hukum sebagaimana telah penulis sebutkan di atas, namun realitasnya wajah penegakan hukum di negri ini jauh dari apa yang diharapkan, yakni hukum menjadi panglima yang harus membawa perubahan pada bangsa. Era reformasi salah satunya bercita-cita mengedepankan hukum yang mampu pula bekerja dengan efektif di tengahtengah masyarakat, juga keinginan besar untuk mengedepankan moral terhadap hukum dengan didasarkan adanya keinginan untuk melaksanakan hukum, dan mengembalikan kewibawaan hukum.

Berbicara tentang penegakan hukum, penulis selalu teringat sebuah adagium yang berbunyi fiat justisia et pareat mundus ( meskipun dunia akan runtuh hukum harus ditegakkan). Adagium tersebut memberikan gambaran bahwa selain hukum harus ditegakkan juga akan memberikan kepastian hukum, kemanfaatan dan keadilan bagi pencari keadilan. Kepastian, kemanfaatan dan keadilan hukum tidak hanya akan memberikan perlindungan bagi pencari keadilan tetapi juga akan dapat menciptakan ketertiban dalam masyarakat. Keadilan merupakan bagian yang tidak terpisahkan dari hukum itu sendiri. Hukum pada dasarnya berintikan keadilan. Gustav Radbruch menyatakan bahwa keadilan merupakan salah satu nilai-nilai dasar dari hukum. ${ }^{5}$

Semua aparat penegak hukum berkewajiban mewujudkan cita-cita hukum secara utuh, yakni keadilan, kemanfaatan menurut tujuan dan kepastian hukum. Namun amanah yang ideal tersebut belum sepenuhnya membumi, karena kenyataan yang tak terbantahkan dapat dirasakan dan dilihat saat ini adalah kondisi penegakan hukum di Indonesia sudak mencapai titik nadir. Masyarakat tidak menghormati hukum demikian pula wibawa penegak hukum kian merosot, sehingga hukum tidak lagi dapat memberikan rasa aman dan tenteram. Hukum tidak dapat menyelesaikan berbagai berbagai persoalan yang mengedepankan dalam dinamika masyarakat dan kepastian hukum semakin dipertanyakan. ${ }^{6}$ Hukum menjadi bertambah lumpuh menghadapi berbagai pelanggaran dan kejahatan yang terjadi sehingga keadilan menjadi utopia dalam masyarakat. Masyarakat semakin tidak terlindungi, tersubordinasi serta tereksploitasi.

Pemikiran Roscou Pound ${ }^{7}$ yang telah menempel dalam pemikiran penulis adalah law is a tool of social engineering. ${ }^{8}$ Bagi Pound hukum itu

\footnotetext{
${ }^{5}$ Satjipto Rahardjo. Op. Cit., p. 6.

${ }^{6}$ Warassih, Esmi. (2001). Pemberdayaan Masyarakat Dalam Mewujudkan Tujuan Hukum (Proses Penegakan Hukum Dan Persoalan Keadilan). Semarang: Badan Penerbit Universitas Diponegoro.

${ }^{7}$ Sebagaimana telah disampaikan oleh Edi Setiadi (Guru Besar Hukum Pidana dan Hukum Peradilan Pidana Unisba) dalam materi kuliah Teori Hukum, Bandung, 2013, dimana Roscou Pound adalah seorang ahli dan akademisi hukum yang hidup dan dibesarkan di tengah tradisi hukum Common law Amerika. Pound menempuh awal karirnya sebagai
} 
dapat dimanfaatkan sebagai alat rekayasa masyarakat dalam rangka mencapai tujuannya. Pound juga meyakini bahwa hukum itu diselenggarakan dengan tujuan memaksimumkan pemuasan kebutuhan dan kepentingan (interest). Pound cenderung melihat kepentingan (bukan etika atau moral) sebagai unsur hakiki dalam percaturan hukum, dan karena itu pantas dijadikan sebagai konsep jurisprudence. Dikatakan pada hakikatmya hukum itu diperlukan karena dalam kehidupan ini banyak terdapat kepentingan yang minta dilindungi. Pada hakikatnya hak tidak lain dari kepentingan yang dilindungi oleh hukum.

Mukhtar Kusumaatmadja berargumentasi bahwa pendayagunaan hukum sebagai sarana untuk merekayasa masyarakat menurut skenario kebijakan pemerintah (eksekutif) amatlah diperlukan oleh negara-negara yang sedang berkembang, jauh melebihi kebutuhan yang dirasakan negaranegara industri maju yang telah mapan. Negara-negara maju memiliki mekanisme hukum yang telah 'jalan' untuk mengakomodasi perubahanperubahan dalam masyarakatnya, sedangkan negara-negara tengah berkembang tidaklah demikian. Padahal harapan-harapan dan keinginan masyarakat-masyarakat di negara sedang berkembang akan terwujudnya perubahan-perubahan yang membawa perbaikan taraf hidup amatlah besarnya. Melebihi harapan-harapan yang diserukan oleh masyarakatmasyarakat di negara-negara yang telah maju. ${ }^{9}$ Namun yang menjadi kegundahan penulis adalah strata Indonesia dalam kategori development country sejak adanya pemikiran tersebut di era 80 -an sampai dengan detik ini tidak pernah ada pergeseran pada strata yang lebih tinggi. Beberapa kalangan berpendapat justru mungkin kondisinya lebih buruk lagi.

Penggunaan hukum sebagai sarana perubahan masyarakat tidak selalu membawa dampak positif bagi masyarakat yang bersangkutan. Dalam konteks tersebut, Esmi Warassih ${ }^{10}$ mengingatkan bahwa agar para penstudi dan pengguna hukum harus selalu menyadari secara sungguh-sungguh

pengacara dan sebagai auxiliry judge pada Nebraska Supreme Judicial Court, dan sampai menduduki jabatan Guru Besar Hukum pada Universitas Harvard.

${ }^{8}$ Ketika hukum diperankan sebagai alat rekayasa sosial ( law is a tool of social engineering) mau tidak mau menempatkan peraturan perundang-undangan pada posisi yang sangat penting dalam mengatur tata kehidupan masyarakat. Konsep hukum sebagai alat rekayasa sosial pertama kali diperkenalkan oleh Roscou Pound. Mukhtar Kusumaatmadja yang mengetengahkan konsep Pound tentang perlunya memfungsikan law as a tool of social engineering di Indonesia. (lihat Wignyosoebroto, Soetandyo. (1995). Dari Hukum Kolonial Ke Hukum Nasional, Dinamika Sosial Politik Dalam Perkembangan Hukum Di Indonesia. Jakarta: Rajawali Pers, p. 231.

9 Kusumaatmadja, Mokhtar. (1986). Pembinaan Hukum dalam rangka Pembangunan Nasional. Bandung: Binacipta, p. 2-7.

10 Warassih, Esmi. (2005). Pranata Hukum: Sebuah Telaah Sosiologis. Semarang: Suryandaru Utama Semarang. 
bahwa hukum itu tidak begitu saja jatuh dari langit, tetapi ia dibuat dan selalu dalam lingkup sosial tertentu. Dengan meminjam kata-kata Sinzheimer, Esmi Warassih yang merupakan Guru Besar Fakultas Hukum Universitas Diponegoro Semarang ini menegaskan bahwa hukum tidaklah bergerak dalam ruang hampa dan berhadapan dengan hal-hal yang abstrak. Melainkan ia selalu berada dalam suatu tatanan sosial tertentu dan dalam lingkup manusia-manusia yang hidup. ${ }^{11}$

Ada tiga macam kepentingan yang barangkali perlu diketahui, yakni kepentingan individu, kepentingan umum (kepentingan badan-badan pemerintah sebagai pemilik harta kekayaan), dan kepentingan sosial (yaitu kepentingan untuk melindungi dan menegakkan nilai-nilai yang dijunjung tinggi dalam masyarakat seperti halnya keamanan umum, perlindungan sumber daya alam, kemajuan dalam kehidupan politik dan budaya, dan lain sebagainya. Jika pada abad 19 ditengarai hukum lebih banyak mengakui hak-hak individu, maka menurut Pound, pada abad 20 seyogyanya hukum ditelaah untuk lebih mendahulukan kebutuhan, tuntutan dan kepentingan. ${ }^{12}$ Pound berpendapat bahwa pembuat hukum harus mempelajari efek sosial yang mungkin ditimbulkan oleh institusi dan doktrin hukum, berbanding dengan efek yang mungkin ditimbulkan oleh sarana kontrol atau sarana rekayasa lain yang bukan hukum. Dengan anjurannya yang demikian ini sebenarnya Pound telah mengajak masyarakat untuk memperhatikan sosiologi hukum.

Masyarakat dan hukum adalah dua identitas yang tidak bisa dipisahkan. Dalam ilmu hukum, terdapat juga adagium populer Ibi sosietas ibi ius (dimana ada masyarakat disitu ada hukum). Untuk mewujudkan keteraturan dalam masyarakat dibutuhkan struktur tatanan (pemerintahan) yang diikat oleh hukum. Hukum dan moral ibarat dua sisi mata uang. Menurut Thomas Aquinas, perintah moral yang paling dasar adalah melakukan hal baik, menghindari yang jahat. Kaidah-kaidah moral akan mendapat pengakuan yang konkrit ketika di back up oleh aturan hukum. Oleh karenanya keteraturan dalam masyarakat selalu sejalan dengan adanya perilaku moral yang baik yang patuh terhadap aturan hukum yang berkeadilan.

Fenomena hukum dan moral menjadi hal yang banyak dibicarakan saat ini. Kekuasaan yang dimiliki oleh seorang pemimpin tidak diiringi dengan good morality ( penulis mencontohkan misalnya kasus Gubernur non aktif DKI Jakarta Basuki Cahaya Purnama), sehingga perbuatannya seringkali menimbulkan kegaduhan di masyarakat. Moralitas sangat penting

11 Telah dikutip juga oleh Shalihah, Fithriatus. (2015). Buku Ajar Sosiologi Hukum. Pekanbaru: Fakultas Hukum Universitas Islam Riau.

12 Wignjosoebroto, Soetandyo. (2002). Hukum: Paradigma, Metode dan Dinamika Masalahnya. Jakarta: Elsam. 
dalam menjalankan kepemimpinan. Apabila moral pemimpinnya baik maka kekuasaannya akan mensejahterakan, namun jika moral pemimpinnya buruk maka kekuasaannya dapat menyengsarakan.

Dalam hubungan dengan kekuasaan, hukum juga berfungsi sebagai sarana legitimasi bagi kekuasaan formal lembaga-lembaga negara, unit-unit pemerintahan, serta pejabat negara dan pemerintahan. Keabsahan kekuasaan itu dilakukan dengan penetapan landasan hukum bagi kekuasaan itu melalui aturan-aturan hukum. Kemudian agar pelaksanaannya dapat dipertanggungjawabkan secara yurudis dan etis. Dari penjelasan mengenai hubungan ketergantungan antara hukum dan kekuasaan di atas, sebagaimana nampak bahwa hukum dan kekuasaan adalah dua sisi dari satu mata uang yang sama, sangat tergantung dari mana hukum dilihat. Pada stu sisi, hukum adalah kekuasaan atau wewenang legal, dan pada sisi lain hukum itu adalah aturan-aturan untuk mengatur tingkah laku para penyelenggara pemerintahan dalam lalu lintas sosial. Karakteristik hubungan hukum dan kekuasaan terutama dalam konteks legalisasi kekuasaan dan penegakan hukum, dijelaskan oleh Mochtar Kusumaatmadja dengan slogan "hukum tanpa kekuasaan adalah angan-angan, dan kekuasaan tanpa hukum adalah kelaliman". ${ }^{13}$

Ungkapan tersebut mengandung arti, bahwa pada satu sisi, kaidahkaidah hukum tidak akan ada gunanya jika ditegakkan oleh kekuasaan negara, artinya hukum itu hanya dapat ditegakkan jika dengan kekuasaan. Pada sisi lain, ungkapan itu bermakna, bahwa kekuasaan tanpa landasan hukum adalah kesewenang-wenangan, dan berarti tidak akan berdaya guna dan berhasil guna bagi kepentingan masyarakat umum. Sehubungan dengan deskripsi di atas, pokok permasalahannya terletak pada apa yang kan dijadikan parameter legalitas kekuasaan itu. Apakah setiap kekuasaan yang berdasarkan aturan hukum itu dapat diklasifikasikan sebagai kekuasaan yang sah dan oleh karena itu harus diterima dan ditaati. Apakah jika aturan hukum yang dijadikan dasar itu dibuat melalui proses yang tidak sepenuhnya sesuai dengan ketentuan hukum yang berlaku, atau aturan hukum yang dijadikan dasar kekuasaan itu bertentangan dengan nilai kebenaran, keadilan dan kemaslahatan yang merupakan inti dari hukum itu, harus diterima sebagai hukum. Apakah kekuasaan yang sewenang-wenang dapat melahirkan hukum yang berkeadilan (just-law). ${ }^{14}$

Hukum tidak steril dari subsistem kemasyarakatan lainnya. Politik kerapkali melakukan intervensi atas pembuatan dan pelaksanaan hukum

${ }^{13}$ Kusumaatmadja, Mochtar. (2002). Konsep-Konsep Hukum Dalam Pembangunan, Cetakan 1, Edisi 1. Bandung: Alumni, p. 6.

14 Shalihah, Fithriatus. (2015). Buku Ajar Sosiologi Hukum. Pekanbaru: Fakultas Hukum Universitas Islam Riau, p. 76. 
sehingga hukum tidak selalu menjamin kepastian hukum, penegak hak-hak masyarakat atau penjamin keadilan. Pembuatan dan pelaksanaan hukum sangat dipengaruhi oleh konfigurasi politik, konfigurasi politik yang demokratis akan melahirkan hukum yang responsif sementara konfigurasi politik yang otoriter akan melahirkan produk hukum yang represif. ${ }^{15}$ Dampak negatif penggunaan hukum sebagai sarana perubahan masyarakat dalam negara otoriter terlihat sudah secara terang benderang ketika berkuasanya sebuah rezim yang puluhan tahun berkuasa di Indonesia. Rezim tersebut mengatasi semua kekuatan yang ada dalam masyarakat dan birokrasinya sangat menentukan. Partai-partai politik pada era itu tidak mandiri. Keputusan-keputusan di bidang legislasi lebih banyak diwarnai oleh visi politik pemerintah.

Pada tataran empiris, apakah efektifitas penegakan hukum bergantung pada legalitas kekuasaan. Sekalipun hukum sangat erat hubungannya dengan kekuasaan, tetapi studi tentang kekuasaan dalam prespektif hukum masih sangat terbatas sehingga konsep-konsep kekuasaan dalam sisi hukum tidak mengalami banyak kemajuan jika di bandingkan dengan studi politik terhadap kekusaaan. Oleh karena itu konsep-konsep kekuasaan yang berkembang hingga saat ini lebih didominasi oleh pemikiran politik dan sosiologis. Kecenderungan studi hukum lebih terfokus kepada pertama, aspek hukum sebagai kaidah tingkah laku. Dalam konteks ini hukum dikonsepkan sebagai aturan-aturan tingkah laku dalam kehidupan masyarakat yang bersifat memaksa dan jika aturan itu dilanggar maka akan mendapat reaksi dan sanksi negatif dari negara. Jadi hukum dipahami sebagai sesuatu yang seharusnya dilakukan (das sollen) dalam kehidupan masyarakat. Studi hukum lebih terfokus juga pada pemahaman hukum sebagai relitas sosial (das sein). Hukum sebagai kenyataan dapat diamati melalui hukum yang hidup dalam masyarakat atau hukum yang diterapkan melalui lembaga peradilan (the living law), perilaku melanggar hukum, dan perilaku taat hukum sebagai kelompok yang tidak ramah lingkungan, karena tidak dirasakan manfaat kehadirannya dalam masyarakat. ${ }^{16}$

Minimnya kajian hukum dari sisi etis filosofis ternyata telah membuat kalangan hukum kehilangan kemampuan untuk membedakan antara hukum dan kekuasaan, antara hukum dan negara kekuasaan, antara supremasi hukum dan supremasi kekuasaan, karena aturan-aturan (uang dipandang sebagai hukum itu) hanyalah ekspresi dari kekuasaan dalam pengertian hukum itu hanya merupakan daftar urutan kepentingan kelompok pemegang kekuasaan negara (the rulling class). Hukum yang berkarakter demikian semua berfungsi sebagai alat justifikasi berbagai kebijakan penguasa yang

\footnotetext{
${ }^{15}$ MD, Mahfud. (1998). Politik Hukum Indonesia. Jakarta: LP3ES.

${ }^{16}$ Shalihah, Fithriatus. Op.Cit., p. 81.
} 
jika dipandang dari dimensi hukum dalam prespektif filosofis adalah tindakan yang melawan hukum, dan pada gilirannya hanya akan melahirkan sikap saralisasi aturan perundang-undangan, yang bermuara pada hilangnya keberanian untuk melakukan kritik terhadap ketentuan-ketentuan aturanaturan formal yang tidak memnuhi syarat materiil substabtif sebagai hukum, bersamaan dengan merosotnya kepercayaan masyarakat terhadap hukum. ${ }^{17}$

\section{Penutup}

Bagi Pound dengan law is a tool of social engineeringnya hukum itu dapat dimanfaatkan sebagai alat rekayasa masyarakat dalam rangka mencapai tujuannya. Pound juga meyakini bahwa hukum itu diselenggarakan dengan tujuan memaksimumkan pemuasan kebutuhan dan kepentingan (interest). Pound cenderung melihat kepentingan (bukan etika atau moral) sebagai unsur hakiki dalam percaturan hukum. Dikatakan juga pada hakikatnya hukum itu diperlukan karena dalam kehidupan ini banyak terdapat kepentingan yang minta dilindungi, sehingga hak merupakan kepentingan yang dilindungi oleh hukum.

Dampak negatif penggunaan hukum sebagai sarana perubahan masyarakat dalam negara otoriter terlihat sudah secara terang benderang ketika berkuasanya sebuah rezim yang puluhan tahun berkuasa di Indonesia. Rezim tersebut mengatasi semua kekuatan yang ada dalam masyarakat dan birokrasinya sangat menentukan. Partai-partai politik pada era itu tidak mandiri. Keputusan-keputusan di bidang legislasi lebih banyak diwarnai oleh visi politik pemerintah.

Disini hukum telah dijadikan identik dengan kekuasaan, sehingga tidak dapat dibedakan lagi secara tegas, mana hukum mana kekuasaan, mana rechtsstaat dan mana machtstaat, mana negara hukum dan mana negara tirani yang dilegitimasi secara hukum. Hukum yang seharusnya diberi muatan-muatan nilai-nilai kebenaran filosofis yang dideduksi dari asas-asas hukum oleh kekuasaan, pada kenyataanya diberi muatan kekuasaan itu sendiri yang harus dipandang sebagai kebenaran. Manipulasi kebenaran yang terjadi disini berakar penyesatan logika melalui permainan bahasa (language of the game $)^{18}$ bahwa hukum itu sama dengan undang-undang dalam aliran positivisme.

\footnotetext{
${ }^{17}$ Ibid., p. 82.

${ }^{18}$ Sebuah istilah yang disebut oleh Kapitra Ampera, sebagaimana disampaikan dalam materi Kode Etik Profesi pada Pendidikan Khusus Profesi Advokat, di Fakultas Hukum Universitas Islam Riau, Pekanbaru, November 2016.
} 


\section{Daftar Pustaka}

\section{A. Buku}

Ali, Achmad. (2002). Menguak Tabir Hukum (Suatu kajian Filosofis Dan Sosiologis): dalam Tulisan Hukum Sebagai Kenyataan dalam Masyarakat. Jakarta: PT. Toko Gunung Agung Tbk.

Hadjon, Philipus M. dan Djatmiati, Tatiek Sri. (2005). Argumentasi Hukum. Yogyakarta: Gajahmada University Press.

Kusumaatmadja, Mochtar. (2002). Konsep-Konsep Hukum Dalam Pembangunan, Cetakan 1, Edisi 1. Bandung: Alumni. (1986). Pembinaan Hukum dalam rangka Pembangunan Nasional. Bandung: Binacipta.

Marzuki, Peter Mahmud. (2005). Penelitian Hukum. Jakarta: Prenada Media. MD, Mahfud. (1998). Politik Hukum Indonesia. Jakarta: LP3ES.

Rahardjo, Satjipto. (1986). Ilmu Hukum. Bandung: Alumni.

Shalihah, Fithriatus. (2015). Buku Ajar Sosiologi Hukum. Pekanbaru: Fakultas Hukum Universitas Islam Riau.

Warassih, Esmi. (2001). Pemberdayaan Masyarakat Dalam Mewujudkan Tujuan Hukum (Proses Penegakan Hukum Dan Persoalan Keadilan). Semarang: Badan Penerbit Universitas Diponegoro. - (2005). Pranata Hukum: Sebuah Telaah Sosiologis.

Semarang: Suryandaru Utama Semarang.

Wignjosoebroto, Soetandyo. (2002). Hukum: Paradigma, Metode dan Dinamika Masalahnya. Jakarta: Elsam. (1995). Dari Hukum Kolonial Ke Hukum

Nasional, Dinamika Sosial Politik Dalam Perkembangan Hukum Di Indonesia. Jakarta: Rajawali Pers. 